\title{
The Interrelationship Between Faculty Job Satisfaction, Service Quality And Student Satisfaction: The Case Of VNU - International School
}

\author{
Pham Thi Lien*, Do Thi Hoang Xuyen \\ VNU International School, 99 Nguy Nhu Kontum Str., Thanh Xuan District, Hanoi, Vietnam \\ Received 20 April 2017 \\ Revised 11 June 2017, Accepted 28 June 2017
}

\begin{abstract}
This research attempts to evaluate the interrelationship between employee satisfaction, service quality, and customer satisfaction in an educational organization. Specifically, this study explores three major relationships: (1) the relationship between influential factors of job satisfaction and faculty satisfaction; (2) the relationship between faculty satisfaction and service quality; and (3) the relationship between service quality and customer satisfaction. The study uses data collected from the questionnaire survey with 167 responses. As a result, there is a positive relationship between employee satisfaction and service quality and in turn service quality has positive effect on student satisfaction. Three out of six variables relating to job satisfaction (including Salary and Fringe benefits, Recognition, and Communiation) have influential relationship with lecturer job satisfaction in the linear regression analysis. And all the five factors of training service quality have positive relationships with student satisfaction. The paper also gives some recommendations for the school to improve its policies and working environment to enhance lecturer job satisfaction as well as service quality and student satisfaction level.
\end{abstract}

Keywords: Job satisfaction, Lecturer satisfaction, student satisfaction, training service quality.

\section{Research background}

Improving customer satisfaction is one of leading interests of every organization. The more customers feel satisfied with service or product, the more benefits the organization will get.

Harter, Schmidt and Hayes (2002) [1] estimated that the numbers of 7,855 articles have examined the topic of job satisfaction during the period of 1976 - 2000. Many authors have researched on the relationship between

\footnotetext{
${ }^{*}$ Corresponding author. Tel.: 84-983820460.

Email: Lienpt@vnu.edu.vn

https://doi.org/10.25073/2588-1116/vnupam.4091
}

employee satisfaction and service quality or the relationship between service quality and customer satisfaction in different sectors such as pharmaceutical sector, banking sector (Hafeez, 2012) [2], service sector etc. Besides, there are plenty of models of customer satisfaction being created and developed through theoretical researches. Such researches refer to facets influencing on customer satisfaction such as price, customer expectation, brand image, customer features, etc. One of the most-mentioned facets in these theoretical studies states that employee satisfaction has effect on customer satisfaction. 
Nevertheless, there are few studies, especially in higher education, analyzing the interrelation of customer satisfaction, service quality and employee satisfaction. Such study requires different surveys into two subjects including employee and customer. Besides, matching data of such two subjects is also an obstacle in doing research.

This research attempts to evaluate the interrelationship between employee satisfaction, service quality, and customer satisfaction in an educational organization with an empirical study at International School - Vietnam National University, Hanoi (VNU-IS).

\section{Literature review}

\subsection{Employee satisfaction}

Employee satisfaction or job satisfaction is defined in many different ways. Employee satisfaction is the terminology used to describe whether employees are happy, contented and fulfilling their desires and needs at work. Many measures purport that employee satisfaction is a factor in employee motivation, employee goal achievement, and positive employee morale in the workplace [3].

In general, most definitions cover the affective feeling an employee has towards their job. This could be the job in general or their attitudes towards specific aspects of it, such as: their colleagues, salary, or working conditions [4]. In this research, job satisfaction or employee satisfaction is the general psychological state and attitude of employees towards their work.

\subsection{Service quality}

Service quality is a concept that has considerable interest and debate in the research literature because of the difficulties in both defining it and measuring it with no overall consensus emerging on either [5]. There are a number of different "definitions" as to what is meant by service quality. One that is commonly used defines service quality as the extent to which a service meets customers' needs or expectations $[6,7]$. Service quality can thus be defined as the difference between customer expectations of service and perceived service. If expectations are greater than performance, then perceived quality is less than satisfactory and hence customer dissatisfaction occurs [8].

Quality in a service organization is a measure of the range to which the service delivered meets the customer's expectations. Quality in higher education has been identified by Harvey and Knight (1996) [9]. They suggested that quality reflects exceptional, consistency, fitness for purpose, value for money, and transformative. Grönroos (1984) [10] held that service quality is made up of three dimensions "the technical quality of the outcome", "the functional quality of the encounter" and "the company corporate image".

Parasuraman et al. (1985) [8] defined perceived service quality as a form of attitude, related to but not equivalent to satisfaction, resulting from a comparison of expectations with perceptions of performance. He and his partners conceptualized service quality using a disconfirmation model that assesses customer's expectations and perceptions, with development and subsequent refinement in 1988 and 1991 of the SERVQUAL instrumentation [11].

\subsection{Student satisfaction}

Customer satisfaction refers to the customer's overall evaluation of the performance of a service. At the time the customer reaches or exceeds the expectative and satisfaction, he or she can become a loyal customer but it always depends on the personal experience and perception of quality [12].

Satisfaction can be considered as a state felt by a person who has experience performance or an outcome that fulfill his/her expectation. Satisfaction is a function of relative level of expectations and perceives performance. The expectation may go as far as before the students even enter the higher education, suggesting that it is important to the researchers to determine first what the students expect before entering the university. 
Students should be considered as primary customers and educational institutions should focus on student-centered education [13]. In consequence, consumers' satisfaction is nearly the most notable concern of service organizations. Students as customers always have some expectations from universities and when these expectations are met, they grew more satisfied and loyal towards the institute [14].

\subsection{The interrelationship of faculty satisfaction, service quality and student satisfaction}

Since customer satisfaction has been considered to be based on the customer's experience on a particular service encounter, [15] it is in line with the fact that service quality is a determinant of customer satisfaction, because service quality comes from outcome of the services from service providers in organizations.

Studies suggest that employee and customer satisfaction are positively correlated [16, 17]. As suggested by the service-profit chain, providing employees with a superior internal working environment will lead to satisfied employees who are both loyal to the organization and able to provide the customer with an excellent service experience, which will result in satisfied customers.

The internal customer satisfaction would always be a precondition to orientation and satisfaction of the external customer. Kuei found out that there is also evidence confirms the existence link between increased satisfaction among employees, improving the product quality and increase customer satisfaction. This is due to the existence of a positive correlation between internal service quality, satisfaction of employees and retaining customers [18]. Massad, Heckman, and Crowston (2006) [19] also recognize that the service provided by employees help to build a good relationship with customers and in some cases, increases their loyalty.

In order to make students understand the value of their education and make them satisfied with their overall experience, satisfied faculty members are needed. A study that attempted to discover factors of education service contributes the most to students ${ }^{\text {ee }}$ satisfaction level, identified lecturer, and faculty as significant affecting factor. Faculty will be effective and competent in achieving the desired learning outcomes, provided they are satisfied with their profession. When students are satisfied with their faculty and institute, they are likely to become more involved with their studies and give better results.

As Deming (1986) [20] commented, most people form their opinions based on the people that they see, and they are either dissatisfied or delighted, or some other point on the continuum in between. In order to deliver high quality services to students, universities must manage every aspect of the student's interaction with all of their service offerings and in particular those involving its people. Services are delivered to people-by-people, and the moments of truth can make or break a university's image. In order to deliver total student satisfaction, all employees of a university should adhere to the principles of quality customer service, whether they be front-line contact staff involved in teaching or administration, or non-contact staff in management or administrative roles.

Satisfied customers are loyal, and satisfied students were likely to attend another lecture delivered by the same lecturer or opt for another module or course taught by her $/ \mathrm{him}$. Hill et al. (2003) [21] utilized focus groups to determine what quality education meant to students. The most important theme was the quality of the lecturer including classroom delivery, feedback to students during the session and on assignments, and the relationship with students in the classroom.

\subsection{Research framework and hypotheses}

Based on the literature review, the six following dimensions are used for analysing job satisfaction in this research, including salary and fringe benefits, promotion and contingent 
rewards, supervision, operating procedures, co-workers, and communication. These dimensions are Spector (1997) [22] dimensions with some combination and changes for being suitable with Vietnam context.

Table 1. Dimensions of job satisfaction and service quality based on Spector (1997) [22] and

Parasuraman (1985) [8] research

\begin{tabular}{|c|c|}
\hline Dimensions & Definition \\
\hline $\begin{array}{l}\text { Salary and } \\
\text { Fringe benefits }\end{array}$ & $\begin{array}{l}\text { Satisfaction with salary, salary } \\
\text { increase and monetary and non- } \\
\text { monetary fringe benefits }\end{array}$ \\
\hline $\begin{array}{l}\text { Promotion and } \\
\text { Contingent } \\
\text { rewards } \\
\text { (recognition) }\end{array}$ & $\begin{array}{l}\text { Satisfaction with promotion } \\
\text { opportunities, appreciation, } \\
\text { recognition and rewards for good } \\
\text { work }\end{array}$ \\
\hline Supervision & $\begin{array}{l}\text { Satisfaction with person's direct } \\
\text { supervision }\end{array}$ \\
\hline $\begin{array}{l}\text { Operating } \\
\text { procedures }\end{array}$ & $\begin{array}{l}\text { Satisfaction with operating } \\
\text { policies and procedures }\end{array}$ \\
\hline Co-workers & Satisfaction with co-workers \\
\hline Communication & $\begin{array}{l}\text { Satisfaction with communication } \\
\text { within the organization }\end{array}$ \\
\hline Reliability & $\begin{array}{l}\text { The ability to perform the } \\
\text { promised service dependably and } \\
\text { accurately }\end{array}$ \\
\hline Assurance & $\begin{array}{l}\text { The knowledge, courtesy of } \\
\text { employees and ability to convey } \\
\text { trust and confidence in the } \\
\text { customer towards the service } \\
\text { provider }\end{array}$ \\
\hline Tangibles & $\begin{array}{l}\text { The appearance of physical } \\
\text { facilities, equipment, personnel, } \\
\text { and communication materials }\end{array}$ \\
\hline Empathy & $\begin{array}{l}\text { The provision of caring, } \\
\text { individualized attention provided } \\
\text { to customers }\end{array}$ \\
\hline Responsiveness & $\begin{array}{l}\text { The willingness to help customers } \\
\text { and to provide prompt service }\end{array}$ \\
\hline
\end{tabular}

The authors apply RATER dimensions of service quality in Parasuraman's research to assess the higher education service quality in VNU-IS, including reliability, assurance, tangibles, empathy, and responsiveness.

There are total of 12 hypotheses formulated. The first six hypotheses are formulated to test the relationship between each influential factor of job satisfaction and faculty satisfaction. The next five hypotheses are formulated to examine the relationship between each dimension of service quality and student satisfaction. The twelfth hypothesis studies the relationship between faculty satisfaction and service quality.

\subsection{Salary and fringe benefits}

Although money is important to individuals, research has shown that individuals earn more does not mean they feel satisfied in their jobs [23]. High salary is necessary, however, the more important factor is the fairness of paying salary that has strong correlation with job satisfaction and employee motivation. Spector (1997) [22] divides fringe benefits into monetary and non-monetary benefits. Increasing intrinsic and extrinsic fringe benefits that attract an employee's attention may subsequently increase their performance and induce higher levels of organizational commitment [24]. In Vietnam, we combine these two dimensions into one because Vietnamese employee seems to care more about the total benefits, not only salary. This is specially true for people working in public education institutions.

Hypothesis 1 (H1): There is a positive relationship between 'salary and fringe benefits' and lecturer job satisfaction.

\subsection{Recognition}

Perceptions of fairness are important determinants of people's behavior and reactions to work [23]. According to Martins and Coetzee (2007) [25], employee motivation and organizational culture are affected by how an employee's needs and objectives are integrated with the needs and objectives of the organization. Promotions provide opportunities for personal growth, more responsibilities and increased social status [26]. Job satisfaction is likely to be experienced by individuals who perceive promotional opportunities to be fair $[22,26]$. 
Employee dissatisfaction may result if an employee perceives that their efforts are not recognized or that their rewards are not equitable, tied to their performance or tailored to their needs [26]. Contingent rewards support the reinforcement theory of motivation, in terms of which performance-relevant behaviors will increase in frequency if rewarded [23]. In this research we combine this two factors into one called Recognition

Hypothesis 2 (H2): There is a positive relationship between Recognition and lecturer job satisfaction.

\subsection{Relationship with supervisors}

A direct supervisor's behavior is also a determinant of job satisfaction [22]. Employee satisfaction increases when the direct supervisor is understanding, friendly, offers praise for good performance, listens to employees' opinions and shows personal interest in them [26]. So, hypothesis 3 is proposed.

Hypothesis 3 (H3): There is a positive relationship between relationship with supervisors and lecturer job satisfaction.

\subsection{Relationship with colleagues}

Having friendly and supportive co-workers leads to increased job satisfaction [26]. An employee's coworkers, the groups they belong to, and the culture to which an individual is exposed all have the potential to influence job satisfaction.

Hypothesis 4 (H4): There is a positive relationship between relationship with coworkers and lecturer job satisfaction.

\subsection{Operating procedures}

Operational procedures include all of regulations, rules, procedures and requirements in work with which employees have to comply. The more transparent, simple the work is, the more employees feel satisfied [22].

Hypothesis 5 (H5): There is a positive relationship between operating procedures and lecturer job satisfaction.

\subsection{Communication}

The formation of specific goals, feedback on progress towards these goals, and reinforcement of desired behavior all stimulate motivation and require communication. The fewer distortions, ambiguities, and incongruities occurring in communication within organizations, the more satisfied employees will feel with regard to their work [26].

Hypothesis 6 (H6): There is a positive relationship between communication and lecturer job satisfaction.

After exploring the links of impact factors to faculty satisfaction, then, to identify the correlation between general faculty satisfaction and service quality, the following hypothesis is formulated:

Hypothesis 12 (H12): There is a positive relationship between faculty satisfaction and service quality.

\subsection{Reliability}

Reliability depends on handling customers' services problems; performing services right the first time; provide services at the promised time and maintaining error-free record. Furthermore, they stated reliability as the most important factor in conventional service. Reliability also consists of accurate order fulfillment; accurate record; accurate quote; accurate in billing; accurate calculation of commissions; keep services promise. He also mentioned that reliability is the most important factor in banking services [27].

Hypothesis 7 (H7): There is a positive relationship between reliability and student satisfaction.

\subsection{Assurance}

Parasuraman et al. (1985) [8] defined assurance as knowledge and courtesy of employees and their ability to inspire trust and confidence. According to Saad Andaleeb and Conway (2006) [28] assurance may not be so important relative to other industries where the risk is higher and the outcome of using the service is uncertain. Assurance means the polite 
and friendly staff, provision of financial advice, interior comfort, eases of access to information and knowledgeable and experienced management team.

Hypothesis 8 (H8): There is a positive relationship between assurance and student satisfaction.

\subsection{Tangibles}

Parasuraman et al. (1985) [9] defined tangibility as the appearance of physical facilities, equipment, personnel, and written materials. Tangibility referred to modern looking equipment, physical facility, employees are well dressed, and materials are visually appealing.

Hypothesis 9 (H9): There is a positive relationship between tangibles and student satisfaction.

\subsection{Empathy}

Empathy is defined empathy as the caring and individual attention the firm provides its customers [8]. It involves giving customers individual attention and employees who understand the needs of their customers and convenience business hours. There are several ways that empathy can be provided: knowing the customer's name, his preferences, and his needs. Many small companies use this ability to provide customized services as a competitive advantage over the larger firms [29].

Hypothesis 10 (H10): There is a positive relationship between empathy and student satisfaction.

\subsection{Responsiveness}

Responsiveness "is the willingness to help customers and provide prompt service" [29]. This dimension is concerned with dealing with the customer's requests, questions, and complaints promptly and attentively. It is also involves understanding needs and wants of the customers, convenient operating hours, individual attention given by the staff, attention to problems and customers ${ }^{\text {ee }}$ safety in their transaction [30].
Hypothesis 11 (H11): There is a positive relationship between responsiveness and student satisfaction.

\section{Research method}

Two questionnaires were developed based on Spector's research (1997) [22] of the influential factors of job satisfaction and SERVQUAL dimensions of service quality with some small modifications for the questionnaire to be suitable with education field in Vietnam. The structure of the 2 questionnaire surveys includes three parts: Part 1 with demographic information, Part 2: Lecturer job satisfaction, Part 3: Faculty engagement and expectations for lecturer survey; Part 1 with demographic information, Part 2: student satisfaction, Part 3: Student experiences and expectations for student survey. A five-point Likert-type scale was applied to measure items used in the questionnaire developed for this study.

Lecturer survey questionnaire includes 37 items representing six influential dimensions affecting employee satisfaction, namely Salary and Fringe benefits ( 7 items), Recognition (8 items), relationship with colleagues (4 items), relationship with supervisors (4 items), operating procedures (4 items), and communication (5 items); and five items representing overall satisfaction of lecturer job satisfaction.

The scale of service quality applies the SERVQUAL questionnaire to assess students' expectations and perceptions of service quality at VNU-IS. It includes 26 items representing the five service quality dimensions, namely reliability (4 items), assurance (6 items), tangibles (7 items), empathy (5 items), and responsiveness (4 items); and five items representing overall satisfaction of service quality.

A sample of 150 students and 70 faculties and staff was expected to involving in collection process of quantitative data for the study. Finally, 107 respondents from students (including 86 online surveys and 21 printed surveys) and 60 answers from faculties 
(including 29 online surveys and 31 printed surveys) were returned, which represents about $70 \%$ and $62 \%$ respectively response rate of each subject.

\section{Research results}

Before testing hypotheses, it is necessary to assess the reliability and value of the scale. Therefore, to prove the accuracy and reliability of scales of service quality and job satisfaction, we apply Exploratory Factor Analysis method (EFA for short). Items with factor loadings bigger than 0.5 will be kept for further analysis. After processing KMO and Bartlett's Test for each factor of job satisfaction and service quality, it is observed that variables of each factor have correlation in whole scale $(0.5 \leq$ $\mathrm{KMO} \leq 1)$.

Cronbach's Alpha coefficient is used to verify the reliability of the scale. It removes inappropriate variables for research model.

Table 2. Cronbach's Alpha coefficient of dimensions in the research framework

\begin{tabular}{clcc}
\hline No. & Dimensions & $\begin{array}{c}\text { Cronbach's } \\
\text { Alpha }\end{array}$ & $\begin{array}{c}\text { N of } \\
\text { Items }\end{array}$ \\
\hline 1 & Recognition & .924 & 10 \\
2 & $\begin{array}{l}\text { Relationship with co- } \\
\text { workers }\end{array}$ & .892 & 8 \\
3 & Relationship with & .863 & 4 \\
& supervisors & .898 & 4 \\
4 & Pay & .853 & 4 \\
5 & Operating Procedures & .778 & 4 \\
6 & Communication & .929 & 5 \\
7 & Reliability & .874 & 6 \\
8 & Assurance & .867 & 5 \\
9 & Tangibles & .894. & 5 \\
10 & Empathy & .870 & 4 \\
10 & Responsiveness & 0.71 & 5 \\
11 & Overall lecturer job & & \\
& satisfaction & & \\
13 & Overall students & 0.824 & 5 \\
\hline
\end{tabular}

From Table 2, all Cronbach's Alpha coefficients of each dimension are bigger than 0.7 . Then data are continued to be used to test hypotheses with correlation analysis and linear regression.

The correlation analysis was conducted and the result showed that there were high correlation coefficients among the six factors and there are significant correlations between the lecturer job satisfaction and all six factors. The same happens with student satisfaction and the four factors of service quality.

Regression analysis was conducted with summarized result in Table 3 for student satisfaction and Table 4 for Faculty satisfaction and in.

The result with adjusted R-square value of .53 indicates that 53 per cent of the variance in student satisfaction can be explained by five variables of training quality including Reliability, Responsiveness, Assurance, Empathy and Tangible.

Table 3 shows the significant impact on student satisfaction of all the five factors of training service quality with beta coefficient of each independent variable, its significant level (all of them are less than 0.05) and appropriate values of Tolerance $(>0.0001)$ and VIF $(<10)$.

That means these five variables (Reliability, Responsiveness, Assurance, Empathy and Tangible) have influential relationship with dependent variable Student satisfaction with different level of impacts showing different values of Beta coefficient. The positive value of Beta index (Beta $>0)$ means that independent variables positively influence on student satisfaction.

The result with adjusted R-square value of .63 indicates that 63 per cent of the variance in lecturer satisfaction can be explained by six variables including salary and fringe benefits, recognition, supervision, operating procedures, co-workers, and communication.

Table 4 shows the significant impact on job satisfaction of three factors having $p$ values less than 0.05. These factors are Salary and Fringe benefits, Recognition, and Communication with beta coefficient of $0.236,0.566$ and 0.527 respectively and appropriate values of Tolerance $(>0.0001)$ and VIF $(<10)$. 
Other three factors including Relationship with Supervisors, Operating procedures, Relationship with co-workers showed no significant impact on lecturer job satisfaction (with $\mathrm{p}$ values bigger than 0.05 ).

Table 3. Linear coefficients of independent variables in regression analysis

\begin{tabular}{lcccc}
\hline & Beta & Sig. & Tolerance & VIF \\
\hline RELIABILITY & .136 & .012 & .305 & 1.300 \\
RESPONSIVENESS & .066 & .000 & .343 & 1.748 \\
ASSURANCE & .110 & .000 & .266 & 2.247 \\
EMPATHY & .155 & .027 & .300 & 1.642 \\
TANGIBLE & .537 & .013 & .504 & 1.017 \\
\hline
\end{tabular}

a. Dependent Variable: Student Satisfaction

Table 4. Linear coefficients of independent variables in regression analysis

\begin{tabular}{lccll}
\hline & Beta & Sig. & Tolerance & VIF \\
\hline Salary and Fringe benefits & .236 & .012 & .302 & 1.200 \\
Recognition & .566 & .001 & .435 & 1.648 \\
Relationship with supervisors & .113 & .141 & .265 & 2.146 \\
Operating procedures & .152 & .067 & .300 & 1.632 \\
Relationship with Co-workers & .137 & .073 & .306 & 1.016 \\
Communication & .527 & .013 & .504 & 1.320 \\
\hline
\end{tabular}

b. Dependent Variable: Lecturer job Satisfaction

The regression analysis for job satisfaction and service quality was implemented with results supported the hypothesis 12 .
Regression results are summarized in Table 5. Nine hypotheses $\mathrm{H} 1, \mathrm{H} 2$ and $\mathrm{H} 6, \mathrm{H} 7, \mathrm{H} 8$, H9, H10, H11, H12 are supported by the data while three other hypotheses $\mathrm{H} 3, \mathrm{H} 4$ and $\mathrm{H} 5$ are not supported by the data.

Table 5. Testing results

\begin{tabular}{|c|c|c|}
\hline Hypothesis & Content & Result \\
\hline H1 & $\begin{array}{l}\text { There is a positive relationship between Salary and fringe benegits and lecturer job } \\
\text { satisfaction. }\end{array}$ & Supported \\
\hline $\mathrm{H} 2$ & There is a positive relationship between recognition and lecturer job satisfaction. & Supported \\
\hline $\mathrm{H} 3$ & $\begin{array}{l}\text { There is a positive relationship between Relationship with Supervisors and lecturer } \\
\text { job satisfaction. }\end{array}$ & $\begin{array}{l}\text { Not } \\
\text { supported }\end{array}$ \\
\hline $\mathrm{H} 4$ & $\begin{array}{l}\text { There is a positive relationship between Relationship with co-workers and lecturer } \\
\text { job satisfaction. }\end{array}$ & $\begin{array}{l}\text { Not } \\
\text { supported }\end{array}$ \\
\hline H5 & $\begin{array}{l}\text { There is a positive relationship between operating procedures and lecturer job } \\
\text { satisfaction. }\end{array}$ & $\begin{array}{l}\text { Not } \\
\text { supported }\end{array}$ \\
\hline H6 & There is a positive relationship between communication and lecturer job satisfaction. & Supported \\
\hline H7 & There is a positive relationship between Reliability and student satisfaction. & Supported \\
\hline H8 & There is a positive relationship between Assurance and student satisfaction. & Supported \\
\hline H9 & There is a positive relationship between Tangibles and student satisfaction. & Supported \\
\hline
\end{tabular}




\begin{tabular}{lll}
\hline H10 & There is a positive relationship between Empathy and student satisfaction. & Supported \\
H11 & $\begin{array}{l}\text { There is a positive relationship between Responsiveness and student } \\
\text { satisfaction. }\end{array}$ & Supported \\
H12 & There is a positive relationship between faculty satisfaction and service quality. & Supported \\
\hline
\end{tabular}

\section{Findings and discussions}

We see from Table 5 that only 3 out of six hypotheses relating to job satisfaction are supported by the data. Of which Recognition (H2) has biggest positive impact on lecturer job satisfaction. This dimension contains factors of contingent rewards and promotion opportunities. The merit reward system, advancement prospect have significant impacts on the retention of lecturers at workplace. This finding aligns with the results from other research as mentioned in the previous section. So, in order to improve Recognition factor, universities should develop a transparent performance evaluation system. The obviousness and fairness are two of the most substantial factors to achieve lecturer job satisfaction. Besides, the merit reward should be as clear as possible. When an employee's voice is respected and listened to, he/she will be motivated to contribute more for organization. The recognition by peers or leaders definitely makes staff feel confident when doing their tasks. Giving praises or compliments and the way leaders do it also affect the faculty job satisfaction. Every single activities relating to reward, promotion has impact on faculty job satisfaction. How to treat employee equally and make them pleased with organization culture and policies is an art in human resourse management.

Additionally, communication (H6) strongly influences on lecturer job satisfaction. In this dimension, $54.24 \%$ of faculties declare that their opinions are respected and listened to at workplace. Moreover, $73.33 \%$ of them agree that they understand their job responsibilities/duties and the performance expectations for their positions. In addition, most of them (54.24\%) believe that they receive adequate training to perform their jobs. It proves that the information interaction in the university workplace is considerable.

Salary and Fringe benefits (H1) is another factor having positive influence on lecturer job satisfaction. This means salary and other fringe benefits like insurance, annual leave, maternity leave, etc. play important role for lecturers to feel please with their job.

The other three factors, including Relationship with supervisors and Relationship with co-workers as well as Operating procedures at the university have no statistical significant relationship with lecturer job satisfaction. This findings are not aligned with some other research about job satisfactions. The reason could be education is really a specific and different from other fields. In academic environment, lecturers work relatively independant from their colleagues. So, relationship with other colleagues (co-workers) has no significant effects on their job satisfaction. Moreover, lecturers have freedom in academic jobs that relationship with supervisors does not affect so much on their job and in turn, on their level of job satisfaction.

For student satisfaction analysis: Tangibles factor (H9) has remarkable relationship with student satisfaction. This consideration is based on the personal observations of students on the academic facilities, physical support during their learning time. A large proportion $(44.76 \%)$ of student disagree that academic facilities are adequate to meet the professional and practices. Correspondingly, $45.71 \%$ of customers do not believe that campus facilities (including Wi-Fi, elevator) are well maintained. Accordingly, $35.24 \%$ of them complain that classes are not well prepared and organized (facilities, learning materials). However, 
$36.19 \%$ of them recognize the effort of the school in providing the needed literature to students such as books, journals, magazines, newspapers, etc. in English language. In general, student does not feel satisfied with the campus facilities. So, this area needs to be improved first to achieve higher student satisfaction.

Empathy (H10) has a second strong relationship with student satisfaction. This dimension includes the perceptions of student in context of the willingness to help of faculties, the convenient approach to faculties, and the fairness of faculties in treatment. Based on statistics results, $81.9 \%$ of students confirm that lecturers and academic faculties are willing to help with their concerns. Similarly, $86.54 \%$ of them feel that lecturers are fair and unbiased in their treatment to students. Moreover, 55.24\% of them feel neutral in case of lecturers and academic faculties understand their needs. That means most of students feel pleased with faculty performance but some are still unsatisfied because there is the differences between what students need and what faculties support.

In addition, assurance and reliability factors (H8 and H7) also have positive effects on student satisfaction. These factors include the viewpoints of students in context of the qualifications of lecturers, the reliability of academic curriculum and the possibility of the school and lecturers to deliver their promises to students. The majority of students (60.95\%) indicate that lecturers have extensive knowledge of their subjects. Furthermore, only $26.92 \%$ of student claim that the school curriculum satisfies the requirements for professional development of student in future. Though to develop a practical curriculum of university level is not an easy task, it is important to set up a trust for student. The more they feel satisfied with their institutions, the more students feel secure about the future education.

The last factor having a correlation with student satisfaction is responsiveness (H11).
This shows the students' judgments on intangibles elements such as the attitude and punctuality of faculties in supporting students as well as the regulations of institution. An important ratio $(46.15 \%)$ shows that academic faculties solve students' problems at a promised time. Moreover, $47.63 \%$ of students agree that academic faculties show positive attitude in solving students' problems. Generally, the student satisfaction towards this dimension is acceptable $($ Mean $=3.1619)$.

Though all five influential factors have satisfactory mean indexes $(>3.0)$, the overall satisfaction of student is low (Mean $=2.8183)$. The data processing illustrates that only a fifth $(25.71 \%)$ of students feel satisfied with their decisions to study at the school, whereas, $35.24 \%$ of them feel dissatisfied with their enrollment at the school and $39.43 \%$ of them deny recommending the school to friends or family members. With this level of student satisfaction, the school should pay more attention to improve these five factors relating to training service quality in order to increase the satisfaction level.

\section{Conclusion}

This paper studies factors affecting lecturer job satisfaction and student satisfaction with training service quality in VNU-IS. The analysis of data collected from questionnaire surveys with 167 responses showed that three out of six variables relating to job satisfaction (including Salary and Fringe benefits, Recognition, and Communiation) have influential relationship with lecturer satisfaction in the linear regression analysis. The school should improve its policies and working environment relating to these three factors to enhance lecturer job satisfaction level with the priority given to factors having stronger effects on lecturer job satisfaction. So, Recognition, Communication and Salary and Fringe benefits should be the first three factors to focus on. Then, other three factors should be taken into account for enhancing lecturer job satisfaction: 
Relationship with supervisors, Relationship with co-workers, and Operating procedures.

Moreover, the five variables of training service quality (including Empathy, Assurance, Tangibles, Reliability and Responsiveness) have influential relationship with student satisfaction. The school should improve its training quality to enhance student satisfaction level through improving these five factors with the priority given to factors having stronger effects to student satisfaction. So, Tangibles and Empathy should be the first two factors to improve. That means the school should focus more on improving their facilities like lecturing room, campus, internet, teaching materials and library, etc. to gain higher student satisfaction. Besides, Empathy dimension including the willingness to help of faculties and staff, the convenient approach to faculties and staff, and the fairness of faculties in treatment also needs to pay attention to, in order to better meet student needs and gain their satisfaction.

Then, other three factors should be taken into account in the following order: Reliability, Assurance and Responsiveness.

A limitation of this study is moderate sample size, which includes a total of 167 responses for the survey of lecturers and students working and studying at VNU-IS using a convenient sample. Further research could be done by surveying more lecturers and more students in other universities to have deeper understanding about the issue.

\section{References}

[1] Harter, J., Schmidt, F. and Hayes, T. (2002). Business-unit-level relationship between employee satisfaction, employee engagement, and business outcomes: A meta-analysis. Journal of Applied Psychology, 87(2), pp.268-279.

[2] Hafeez, S. (2012), The Impact of Service Quality, Customer Satisfaction and Loyalty Programs on Customer's Loyalty: Evidence from Banking Sector of Pakistan, International Journal of Business and Social Science, 3(16).

[3] Heathfield, S. (2016). How (and Why) to Foster Employee Satisfaction. [online] About.com Money.
Available at: http://humanresources.about.com/od/employeesurve yl/g/employee_satisfy.htm [Accessed 29 Jan. 2017].

[4] Thompson, E. and Phua, F. (2012). A Brief Index of Affective Job Satisfaction. Group \& Organization Management, 37(3), pp.275-307.

[5] Wisniewski, M. (2001), Assessing customer satisfaction with local authority services using SERVQUAL, Total Quality Management, 12(78), pp.995-1002.

[6] Lewis, B. and Mitchell, V. (1990), Defining and Measuring the Quality of Customer Service, Marketing Intelligence \& Planning, 8(6), pp.11-17.

[7] Dotchin, J. and Oakland, J. (1994), Total Quality Management in Services, International Journal of Quality \& Reliability Management, 11(3), pp.9-26.

[8] Parasuraman, A., Zeithaml, V. and Berry, L. (1985), A Conceptual Model of Service Quality and Its Implications for Future Research, Journal of Marketing, 49(4), p.41.

[9] Harvey, L. and Knight, P. (1996), Transforming higher education, Buckingham [England], Society for Research into Higher Education.

[10] Grönroos, C. (1984), A Service Quality Model and its Marketing Implications, European Journal of Marketing, 18(4), pp.36-44.

[11] Parasuraman, A., Berry, L. and Zeithaml, V. (1991), Refinement and reassessment of the SERVQUAL scale, Journal of Retailing, 67(4), pp.420-450.

[12] Yu, C., Wu, L., Chiao, Y. and Tai, H. (2005), Perceived quality, customer satisfaction, and customer loyalty: the case of lexus in Taiwan. Total Quality Management \& Business Excellence, 16(6), pp.707-719.

[13] Qureshi, T., Shaukat, M. and Hijazi, S. (2010), Service Quality SERVQUAL model in Higher Educational Institutions, What factors are to be considered?, Interdisciplinary Journal of Contemporary Research in Business, 2(5).

[14] Juillerat, S. and Schreiner, L. (1996), The role of student satisfaction in the assessment of institutional effectiveness, Assessment Update, 8(1), pp.8-9.

[15] Cronin, J. and Taylor, S. (1992). Measuring Service Quality: A Reexamination and Extension. Journal of Marketing, 56(3), p.55.

[16] Spinelli, M. and Canavos, G. (2000). Investigating the Relationhip between Employee Satisfaction and Guest Satisfaction. Cornell Hotel and Restaurant Administration Quarterly, 41(6), pp.29-33. 
[17] Matzler, K. and Renzl, B. (2007). Assessing asymmetric effects in the formation of employee satisfaction. Tourism Management, 28(4), pp.1093-1103.

[18] Kuei, C. (1999). Internal service quality - an empirical assessment. Int J Qual \& Reliability Mgmt, 16(8), pp.783-791.

[19] Massad, N., Heckman, R. and Crowston, K. (2006). Customer Satisfaction with Electronic Service Encounters. International Journal of Electronic Commerce, 10(4), pp.73-104.

[20] Deming, W. (1986). Out of the crisis. Cambridge, Mass.: Massachusetts Institute of Technology, Center for Advanced Engineering Study.

[21] Hill, Y., Lomas, L. and MacGregor, J. (2003). Students' perceptions of quality in higher education. Quality Assurance in Education, 11(1), pp.15-20.

[22] Spector, P. (1997). Job Satisfaction. Thousand Oaks: SAGE Publications.

[23] Spector, P. (2008). Industrial and Organizational Psychology. Hoboken, John Wiley \& Sons.

[24] Suliman, A. and Iles, P. (2000). Is continuance commitment beneficial to organizations? Commitment-performance relationship: a new look. Journal of Managerial Psychology, 15(5), pp.407-422.

[25] Martins, N. and Coetzee, M. (2007). Organisational culture, employee satisfaction, perceived leader emotional competency and personality type: An exploratory study in a South African engineering company. SA Journal of Human Resource Management, 5(2).

[26] Robbins, S. (1993). Organizational Behavior. Englewood Cliffs, N.J.: Prentice Hall.

[27] Yang, Z. and Fang, X. (2004). Online service quality dimensions and their relationships with satisfaction. Int $\mathrm{J}$ of Service Industry Mgmt, 15(3), pp.302-326.

[28] Saad Andaleeb, S. and Conway, C. (2006). Customer satisfaction in the restaurant industry: an examination of the transaction-specific model. Journal of Services Marketing, 20(1), pp.3-11.

[29] Zeithaml, V., Bitner, M. and Gremler, D. (2006), Services marketing, New York, N.Y.: Irwin.

[30] Kumar, M., Tat Kee, F. and Taap Manshor, A. (2009). Determining the relative importance of critical factors in delivering service quality of banks. Managing Service Quality, 19(2), pp.211-228. 